\title{
EL AUTOR EN SU DOBLE: DON PÍO BAROJA Y EL ÁRBOL DE LA CIENCIA
}

\author{
JAVIER SALAZAR RINCÓN \\ Centro Asociado de la UNED \\ La Seu d'Urgell
}

En La intuición y el estilo, volumen quinto de sus Memorias, Pío Baroja reconoce que:

...es imposible no tener simpatía o antipatía deliberada por los tipos inventados por el autor, que, en general, no son más que desdoblamientos de sí mismo'.

Y en efecto, desde que el joven Pío inicia su carrera literaria en la última década del siglo, y hasta al menos 1912 -año en que muere su padre y él pasa a ser el «hijo de familia que había aceptado la soltería de modo resignado" ${ }^{2}$ - casi todas sus novelas se nos muestran entreveradas de experiencias personales y recuerdos íntimos apenas encubiertos, y la mayoría de los protagonistas, animados por preocupaciones y esperanzas similares a las que turba-

1 En Pio Baroja, Obras completas, Madrid, Biblioteca Nueva, 2.' edic., 1979, 8 vols., vol. VII, p. 1057. Mientras no se indique lo contrario, todas las citas de la obra de Baroja proceden de esta edición, a la que nos referiremos entre paréntesis con las siglas $O C$, indicando a continuación el volumen en números romanos y las páginas en caracteres arabigos.

2 Julio Caro Baroja, Los Baroja. Memorias familiares, Madrid, Taurus, Col. Persiles, 2.' edic., 1978, p. 71 . 
ron las horas de la juventud y la primera madurez de su creador: Muchos de estos personajes - desde Fernando Ossorio a Juanito Velasco y Luis Murguía - constituyen en conjunto un testimonio autobiográfico de valor inestimable ${ }^{3}$; aunque es sin duda Andrés Hurtado quien más luz arroja sobre la personalidad de nuestro autor en sus años de estudiante y médico ${ }^{4}$, y la novela que protagoniza, El árbol de la ciencia, publicada en 1911, una obra clave en la trayectoria literaria barojiana ${ }^{5}$, y uno de los títulos fundamentales en la novelística española del período 6 .

${ }^{3}$ La coincidencia de la critica sobre este asunto es casi unánime: Toda la obra de Baroja, escribe SALVADOR ClotAS, «podría compararse a una informe y larga autobiografía si no de sus vicisitudes anecdóticas y concretas, sí de su vida mental e intelectual» ( $\ll$ El azar y la intuición. Baroja reconsiderado a través de sus opiniones sobre literatura», en JUAN BENET y otros, Barojiana, Madrid, Taurus, 1972, pp. 113-142, y p. 133 para el fragmento citado); e IsAbel CRIADO Miguel ha señalado como fuente única de la narrativa barojiana «la persona misma del autor, su íntima problemática personal, su autorrealización progresiva" (Personalidad de Pio Baroja. Trasfondo psicológico de un mundo literario, Barcelona, Planeta, 1972, p. 317). Véanse también los trabajos de LuIS SANCHEZ GRANJEL, Retrato de Pfo Baroja, Barcelona, Editorial Bama, 1953, pp. 169 y ss.; y «Autor y personaje en la obra barojiana», Cuadernos Hispanoamericanos, 265-267, julio-septiembre, 1972, pp. 3-10.

4 José Ortega ha recordado acertadamente cómo toda la creación literaria, y la narrativa barojiana de manera muy especial, supone «la búsqueda en cada uno de sus personajes mediante la transitoria negación de sí mismo, de una totalidad humana a la que el novelista-narrador aspira», y en cuanto a El árbol de la ciencia, la obra «resume, quizá mejor que ninguna otra novela del autor vasco, esa búsqueda que el autor-personaje - sujeto y objeto de la experimentación- efectúa para encontrarse a sf́ mismo» [JOSÉ ORTEGA, «Andrés Hurtado: un estudio en alineación. (El árbol de la ciencia)», Cuadernos Hispanoamericanos, 265-67, jul-sept. 1972, pp. 591-599, y 591-92 para ambas citas]. «El árbol de la ciencia [ha escrito Isabel Criado] es el replanteamiento más radical que Pío Baroja hace de su vida; la realidad y el fracaso se presentan con absoluta desnudez y sinceridad. En algunos aspectos, Andrés Hurtado es más Pío Baroja que Baroja mismo, porque lo que el hombre ordinariamente oculta, en momentos de angustiosa crisis vital, lo expresa» (ISABEL CRIADO MIGUEL, op. cit. p. 323). Y Azorín ya señaló años antes: «El árbol de la ciencia resume, mejor que ningún otro libro, el espíritu de Baroja. En sus páginas se puede ver fielmente la sensibilidad, el estilo y la filosoffa de nuestro artista» (AZORTN, Ante Baroja, Zaragoza, Librería General, 1946, p. 76).

5 «Igual que un gran edificio, o un lienzo, la obra de un novelista debería ofrecernos $-y$, en efecto, nos ofrece con frecuencia, si sabemos buscarlo- un centro de atención, una novela privilegiada que nos permita ordenar las demás y entenderlas mejor. Para mí, la novela esencial de Baroja es El árbol de la ciencia» (MANUEL DURÁN, «El Baroja esencial: El árbol de la ciencia», Insula, 308-309, julio-agosto, 1972, p. 14). El propio Baroja ya había señalado en uno de los volúmenes de sus Memorias, el titulado Final del siglo $\mathrm{XIX}$ y principios del $\mathrm{XX}$, que «El arbol de la ciencia es, entre las novelas de carácter filosbfico, la mejor que yo he escrito. Probablemente es el libro más acabado y completo de todos los míos, en el tiempo en que yo estaba en el máximo de energía intelectual. A pesar de su final trágico, no creo que deje un fondo de melancolía. Hay en ella una visión de la vida de tiempos pasados, una recapitulación» (OC, VII, 801).

6 «El árbol de la ciencia es una de las novelas más conmovedoras y entrañables para los españoles que nacieron hacia 1900 . No conozco otro libro que dé más exactamente, más directamente, la desesperanza moral, el desasosiego, la desorientación psicologica de parte de la España de esa 
Pero antes de intentar esclarecer el trasfondo autobiográfico de $E l$ árbol de la ciencia - tarea que nos proponemos en este artículo ${ }^{7}$-, es preciso recordar que ni $E l$ árbol ni las demás novelas en que el autor ha ido hilvanando experiencias y evocaciones del pasado, son en sentido estricto autobiográficas: no se ajustan a la definición de tales escritos formulada por Philippe Lejeune ${ }^{8}$, y que muchos críticos han hecho suya ${ }^{9}$, ni se da en ellas la identidad entre autor, narrador y personaje, que es una de las características diferenciadoras del género $^{10}$. Se trata más bien de relatos autobiográficos de ficción, o novelas autobiográficas, en que el lector, a partir de datos extratextuales, descubre una cierta semejanza entre el autor y el personaje ${ }^{11}$, pero sin que exista el fenómeno que el propio Lejeune ha denominado "pacto autobiográfico», es decir, una identidad, explícita a nivel textual y aceptada por el lector, entre el creador y su criatura ${ }^{12}$.

Así eran las cosas en 1911, fecha en que se publicó El árbol de la ciencia. En los años siguientes irán apareciendo una serie de ensayos que, a modo de fragmentarias memorias, arrojarán nueva luz sobre la vida y temperamento de nuestro autor, y ayudarán de manera decisiva a desvelar el contenido autobiográfico de muchas de sus novelas ${ }^{13}$; y a partir de 1944, sobre todo, el proceso culmina al iniciarse la publicación de las Memorias de Baroja, ya citadas, que

época» (Jonqún CASALduero, «Baroja y Galdós», en Estudios de literatura española, Madrid, Gredos, 3.' edic., 1973, pp. 281-288, y p. 281 para el fragmento que reproducimos). Y para Ángel Valbuena, se trata de «la novela más típica de la generación del 98* (ÁNGEL VALBUENA PRAT, Historia de la Literatura Española, Barcelona, Gustavo Gili, 7.' edic., 1964, 3 vols., vol. III, p. 485).

${ }^{7}$ El tema de este estudio ha sido examinado en parte por KENNETH ELLER, «The Autobiographical Sources of Baroja's El arbol de la ciencia», Revista de Estudios Hispánicos, XII, 1978, pp. 323-335, aunque el artículo es una simple confrontación de algunos acontecimientos y personajes concretos de El árbol con otros del volumen de Memorias titulado Familia, infancia y juventud, «in orden to estimate to what exent the novel is autobiographical» (Ibid., p. 325).

8 «Récit rétrospectif en prose qu'une personne réelle fait de sa propre existence, lorsqu'elle met l'accent sur sa vie individuelle, en particulier sur l'histoire de sa personnalite» (PHILIPPE LEJEUNE, Le pacte autobiographique, Paris, Seuil, Collection Poétique, 1975, p. 14).

9 Véase, entre otros, GeORGE MAY, La autobiografía, México, Fondo de Cultura Económica, 1982, pp. 215-217; José ROMERA CASTILLO, «La literatura, signo autobiografico: El escritor, signo referencial de su escritura», en el volumen conjunto coordinado por el mismo autor, La Literatura como signo, Madrid, Playor, 1981, pp. 13-56; y Dario VIllanueVA, «Para una pragmática de la autobiografiam, en el volumen colectivo, La autobiografia en lengua española en el siglo veinte, Laussane, Hispánica Helvética, 1991, pp. 201-218.

10 Philippe Lejeune, op. cit., pp. 14-15 y ss.

11 Ibid., p. 25; y José Romera Castillo, op. cit., p. 27. Para las relaciones entre autobiografra y novela véase especialmente GEORGE MAY, op. cit., pp. 201 y ss.

12 Phil ippe Lejeune, Ibid., pp. 29 y ss., y passim; y Darío Villanueva, op. cit., pp. 207 y ss.

13 Destaquemos los siguientes títulos: Juventud, egolatría (1917), Las horas solitarias (1918), Intermedios (1931), y La formación psicologica de un escritor (1934), discurso de ingreso en la Real Academia, incluido después en Rapsodias (1936). 
el autor titula Desde la última vuelta del camino, y en las que incluye largos fragmentos de su obra narrativa anterior, sustituyendo el nombre de sus protagonistas por el yo del autor-narrador ${ }^{14}$, con lo que aquellos textos novelescos en que lo ficticio se amalgamaba con los recuerdos íntimos, adquieren ahora el estatuto de auténticas autobiografías, al producirse la identificación explícita del sujeto del enunciado y el sujeto de la enunciación, y de éste con el autor, convertido así en el referente objetivo de ambos ${ }^{15}$.

Este aprovechamiento de materiales narrativos propios en la redacción de unas memorias, además de proporcionarnos un material interesantísimo para estudiar la génesis de los escritos autobiográficos, nos permite establecer una compleja red de relaciones entre la obra narrativa y los libros de memorias del autor: un verdadero espacio autobiográfico ${ }^{16}$ en el que se suman, a la vez que se complementan y contraponen, la compleja ambigüedad de los relatos de ficción y la supuesta exactitud referencial de las confesiones y recuerdos personales, y en el que se nos brinda la oportunidad de leer en clave autobiográfica el conjunto de la novelística barojiana.

Hemos de advertir, no obstante, que el esclarecimiento de las relaciones entre la autobiografía y la ficción, y de ambas con la verdad histórica, constituye un arduo problema, acerca de cuya extrema complejidad nos ilustra ampliamente la obra de Baroja; ya que, en efecto, así como las memorias de cualquier autor son fiables, o verificables al menos, en todo lo referente a acontecimientos, fechas, personajes y otros datos objetivos, no ocurre lo mismo cuando llegamos al terreno del autorretrato y la confesión íntima, en el que son frecuentes el silencio, la manipulación o la tergiversación ${ }^{17}$, y en el que las reflexiones del

14 Al iniciar el volumen titulado El escrito según él y según los críticos, primero de las memorias, el autor nos dice: «Otra cosa que tengo que advertir es que pienso copiarme a veces a mí mismo y utilizar párrafos de otros libros, porque algo dicho con claridad y con sinceridad una vez, yo creo que no se debe cambiar ni se puede mejorar fácilmente. Voy a coger de mis novelas todo lo que tenga aire autobiografico y darlo junto en el mismo libro» (OC, VII, 394). Y, en efecto, en la redacción de sus Memorias, además de reproducir textualmente largos fragmentos de El árbol y más breves de otros textos, al recordar su infancia y adolescencia en Pamplona, Baroja copió literalmente los capitulos relativos a la infancia de dos de sus personajes: Silvestre Paradox, protagonista de la novela del mismo nombre, y Luis Murguia, narrador y personaje principal de La sensualidad pervertida. Y en «París fin de siglo», tercera parte del volumen de las Memorias titulado Final del siglo XIX y principios del XX, nuestro autor aprovecha los recuerdos esparcidos en sus novelas Los últimos románticos y Las tragedias grotescas.

15 Véase PHILIPPE LEJEUNE, op. cit., pp. 35-36.

16 Ibld., p. 43; y GEORGE MAY, op. cit., pp. 220 y ss.

17 George May, op. cit., pp. 89-90; y Jose Romera Castillo, op. cit., p. 52. Curándose en salud, Baroja nos advierte en las primeras líneas de sus Memorias: "Yo no tengo la costumbre de mentir. Si alguna vez he mentido, cosa que no recuerdo, habrá sido por salir de un mal paso. No por pura decoración. Los hechos de la vida están casi siempre tan conectados el uno con el otro, que el mentir para darse tono me parece una estupidez sin objeto» (OC, VII, 389). 
presente se mezclan con lo vivido y sentido en el pasado ${ }^{18}$, y el autor construye la verdad en un complicado proceso de autodescubrimiento y autocreación, a la vez que combina en diversas proporciones la imaginación y la memoria ${ }^{19}$. La novela, por su parte, es un género de ficción en el que supuestamente predomina la fantasía, pero en ella se ofrece al autor amplia libertad para instalarse cómodamente en el interior de su relato a través de un alter ego imaginario, y expresar sin trabas todas aquellas inquietudes, ilusiones, fobias y deseos inconfesables que obligadamente quedan soslayados cuando el creador se expresa con voz propia a través de unas memorias. Por eso en las páginas que siguen nos proponemos observar simultáneamente las dos vertientes de ese espacio autobiográfico barojiano al que hemos aludido, con el fin de completar la veracidad objetiva del relato autobiográfico con esa otra verdad íntima presente en las novelas.

El plagio de su propia obra que Baroja lleva a cabo al redactar su autobiografía, resulta ya evidente en el momento mismo en que iniciamos la lectura de El árbol de la ciencia: la primera parte del libro, titulada «La vida de un estudiante en Madrid", fue reproducida casi en su totalidad y con escasas variaciones en el segundo volumen de las Memorias, titulado Familia, infancia y juventud ${ }^{20}$. Recordémoslo brevemente:

En el año preparatorio de Medicina, durante el curso 1887-88, Baroja asiste a clases de Física, de Mineralogía y de Química: esta última es una grotesca comedia representada por don Ramón Torres Muñoz de Luna en la antigua capilla del Instituto San Isidro (OC, II, 447-51 y VII, 572-79) ${ }^{21}$. Con un suspenso en Química, Baroja veranea en San Sebastián y vuelve pronto a Madrid decidido a estudiar con energía (Andrés permanecerá durante el verano en la capital). Lecturas más amenas que el tomo de Química (la contemplación del vecindario

18 GeORGE MAY, op. cit., pp. 91-92. En La sensualidad pervertida, novela autobiografíca escrita en primera persona y publicada en 1920, que el autor copiará después parcialmente en las $M e$ morias, el propio Baroja nos advierte: «A mis recuerdos de la juventud y de la infancia les ire añadiendo las reflexiones de hoy. Seria más completa una historia autobiografica si se pudieran añadir a los sucesos de la vida pasada las reflexiones y comentarios hechos entonces; pero esto sería muy difícil y, probablemente, una obra de artificio, y yo no soy hábil para el artificio» (OC, II, 848).

19 Véase Paul John Eakin, Fictions in Autobiography. Studies in the Art of Self-Invention, Princeton, Princeton University Press, 1985, pp. 3 y ss.

20 El árbol de la ciencia se encuentra en el volumen II de las Obras completas, pp. 445-569, y las Memorias se publicaron en el volumen VII, pp. 887-1364. Para este período de la biografia de Baroja, puede verse también Miguel Pérez Ferrero, Vida de Plo Baroja, Madrid, Magisterio Español, 1972, pp. 56-69; Teresa GuerRa de Gloss, Pio Baroja en sus memorias, Madrid, Playor, Col. Nova Scholar, 1974, pp. 73 y ss.; y KENNETH ELLER, art. cit., pp. 327-330.

21. Baroja también ha recordado a este personaje, y a otros profesores de San Carlos, en sus Intermedios (1931) (OC, V, 669-70). 
desde la ventana en el caso de Andrés), distraen sin embargo la atención del joven estudiante, quien, a pesar de haber hecho un examen detestable, logra aprobar la asignatura en septiembre gracias a la recomendación de un amigo de la familia, don Fausto Garagarza (de Iturrioz en El árbol de la ciencia) (OC, II, 455-56 y VII, 580).

Durante el curso 1988-89 Baroja estudia Anatomía, asiste a las prácticas de disección, y queda horrorizado ante el terrible espectáculo de la carne humana amontonada en aquel spoliarium, aunque le anima y reconforta su afán «por sorprender la vida» (OC, II, 456-58 y VII, 580-82). Al concluir este segundo año (el tercero de Andrés Hurtado), la familia permanece en Madrid; Baroja pasea con su amigo Riudavets (Montaner en la novela), y frecuenta por las noches el paseo del Prado y los Jardines del Buen Retiro (OC, II, 461-63 y VII, 587).

Comienza el curso 1889-90, Baroja inicia el tercero de su carrera, y los primeros días del otoño madrileño le ofrecen la posibilidad de distraerse en la feria instalada en el paseo del Prado (OC, II, 461 y VII, 587).

Al año siguiente, curso 1890-91, cuarto de la carrera, Baroja asiste a la clase de don José Letamendi, quien, a pesar de su ridícula palabrería, despierta en él un vivo deseo de acercarse a la filosofía ( $O C$, II, 463-66 y VII, 587-89). Traba Andrés Hurtado amistad con Antonio Lamela, estudiante rezagado y trasunto literario de un personaje real, Maximiano Limeses, a quien Baroja conoció años más tarde, en la época en que regentaba la panadería de doña Juana Nessi (OC, II, 466-69 y VII, 648-49) 22. Nuevos motivos de depresión y de melancolía aparecen en la vida de Baroja, y van conformando su temperamento retraído y pesimista: el paso por el hospital de San Juan de Dios, en el que asiste a unos cursos sobre enfermedades venéreas (OC, II, 469-71 y VII, 596-97) el mitin del liceo Rius; las prácticas como alumno interno en el Hospital General, vetusto edificio dominado por la inmoralidad, en el que conoce a personajes extraños, como el hermano Juan ${ }^{24}$, y contempla de cerca la depravación de los alumnos, los médicos y los capellanes de la institución (OC, II, 471-74 y VII, 593-96).

22 KeNNETH ELLER, art. cit., pp. 332-33.

23 Ya en uno de sus artículos juveniles, recordando probablemente estas experiencias, Baroja había escrito: «He visto asilos que son la parodia más terrible de la caridad; hospitales en donde los enfermos mueren abandonados. Y no he visto a nadie que se ocupara en serio de tanta tristeza, de tanta laceria. ¿Es egorsmo monstruoso o es olvido?» («Crónica. Hampa», El Pueblo Vasco, 18 de septiembre de 1903, reproducido en Pio Barosa, Escritos de juventud (1890-1904), prólogo y selección de Manuel Longares, Madrid, EDICUSA, 1972, p. 294).

24 KENNETH ELLER, art. cit., pp. 332-33. 
Otros muchos recuerdos de la vida estudiantil de Baroja aparecen recogidos en El árbol de la ciencia: de un lado la afición a la lectura, obsesiva en nuestro autor ${ }^{25}$, y en la que empezará a cimentar su futura vocación literaria -Dumas, Sue, Montepin, Gaboriau (OC, II, 461 y VII, 576-78)-, sus tempranas inquietudes políticas - Thiers y Lamartine (OC, II, 459 y VII, 597)-, y sus preocupaciones filosóficas - Kant, Fichte, Schopenhauer (OC, II, 465 y VII, 588-89)-; de otro, sus primeros contactos con el Madrid noctámbulo, bohemio y desgarrado: El café del Siglo, los cafés cantantes, los garitos de juego (OC, II, 459-60 y VII, 570-71 y 583-84).

Hay además, en la primera parte de la novela, tres datos esenciales para entender algunos rasgos de la personalidad de Baroja en esa edad temprana: familia y relaciones humanas, contacto con la Universidad y con la práctica médica, entorno social.

La familia de Andrés Hurtado no tiene mucho que ver, en apariencia, con la que se nos describe en Familia, infancia y juventud, y ya en el opúsculo titulado Juventud, egolatría (1917), nuestro autor se cuida de advertimos:

En mi novela El árbol de la ciencia he pintado una contrafigura mía, dejando la parte psicológica y cambiando el medio ambiente del protagonista, la familia y alguna que otra cosa $(O C, \mathrm{~V}, 197)$.

Toda la obra de Baroja, y sobre todo la comprendida entre 1900 y 1912 , está tejida, no obstante, sobre un modelo de relaciones familiares característico y apenas sometido a variaciones: falta de cariño y de un ambiente hogareño, ausencia de los padres y sufrimiento del niño bajo la tutela de parientes tiránicos, actitud de rebeldía y desprecio frente a un padre despótico y arbitrario, imposición de una norma moral rígida por parte de la madre ${ }^{26}$; y si tenemos en cuenta el contenido sincera e intensamente autobiográfico de la mayor parte de la obra barojiana, no es aventurado pensar que algunos de estos episodios reflejan, aunque de forma intensificada, experiencias personales y sentimientos hondamente arraigados en el alma de nuestro autor.

25 En Familia, infancia y juventud, el autor ha recordado: "Yo devoraba en la juventud todo lo que cara en mis manos, principalmente novelas, sin fijarme si el autor tenía fama o no, si era bien o mal considerado por los críticos» (OC, VII, 568). «En Madrid, el poco dinero que tuve cuando era estudiante de Medicina lo dedicaba a comprar novelas en las librerfas de viejo, y me leŕ casi toda la literatura romántica y gran parte de la realista» $(O C, \mathrm{VII}, 576)$.

26 Véase Isabel Criado Miguel, op. cit., pp. 25 y ss. 
El germen íntimo de ese trasfondo familiar de carácter novelesco, cobra pleno sentido en primer lugar a la luz de opiniones como la que aparece en el volumen misceláneo titulado Las horas solitarias (1918), en cuyas páginas el autor confiesa la repugnancia que le inspira la vida familiar en la ciudad, «llena de pequeños cuidados y miserias» $(O C, \mathrm{~V}, 247)$, o al releer artículos como el titulado «La familia y sus víctimas» (1935), en el que Baroja llega a afirmar que «la familia, como todas las instituciones humanas, ha sido un manantial de arbitrariedades, de injusticia y de dolores», ya que en ella hay muchas veces «víctimas y verdugos, sacrificados y sacrificadores, déspotas y esclavos» $(O C, \mathrm{~V}$, 1292-93). Y en cuanto a El árbol de la ciencia, si despojamos algunas páginas de la novela de su envoltura literaria, y las confrontamos con otras fuentes biográficas y autobiográficas, incluidas las tardías Memorias del autor, es posible descubrir, sin cicatrizar aún, algunas de las heridas que la vida familiar debió dejar en el espíritu del joven Pío, y que el hombre maduro nos muestra ahora magnificadas. El padre de Andrés Hurtado, por ejemplo, se caracteriza por una actitud arbitraria y despótica, que choca con el espíritu independiente del hijo ${ }^{27}$ :

Dirigía la casa despóticamente, con una mezcla de chinchorrería y de abandono, de despotismo y de arbitrariedad, que a Andrés le sacaba de quicio.

Era socio de dos casinos; cultivaba amistades con gente de posición y con algunos aristócratas, y administraba la casa de la calle de Atocha, donde vivían (OC, II, 451-52).

Mientras que el volumen de las Memorias titulado Familia, infancia y juventud, ya aludido, aunque los juicios desfavorables sobre el padre quedan notablemente atenuados, no han perdido por completo el tono de reproche ${ }^{28}$ :

Mi padre era hombre alegre y bondadoso, muy preocupado de la opinión de sus antiguos amigos y bastante despreocupado para las cosas propias. Tenía fama de original y era de temperamento bohemio y de carácter algo arbitrario $(O C, \mathrm{VII}, 522)^{29}$.

27 Ibid., pp. 33 y ss.

28 lbid., pp. 104 y ss.

29 El reproche contra las amistades del padre, franco en el texto de El árbol que acabamos de citar, y velado en el de las Memorias, aparece en otros textos de carácter autobiográfico. Así, en Juventud, egolatría, el autor recuerda que don Serafín «tenía el fervor romántico de los hombres de su época; creía mucho en la amistad y, sobre todo, en sus amigos de San Sebastián», y explica a 
Entre padre e hijo existía una incompatibilidad absoluta, completa; no podían estar conformes en nada. Bastaba que uno afirmara una cosa para que el otro tomara la posición contraria $(O C, \mathrm{II}, 452)$.

Escribe Baroja en El árbol, y añade:

Su padre se lo había indicado muchas veces: «Estudia lo que quieras; eso es cosa tuya».

A pesar de decírselo y de recomendárselo, el que su hijo siguiese sus inclinaciones sin consultárselo a nadie, interiormente le indignaba.

Don Pedro estaba constantemente predispuesto contra aquel hijo, que él consideraba díscolo y rebelde $(O C, \mathrm{II}, 453)$.

Aunque en Familia, infancia no es posible hallar opiniones similares, al evocar el afecto que le unía a su madre, nuestro autor afirma que es «más frecuente, $\mathrm{y}$, sin dudar, más natural, la hostilidad clara o velada por el padre» [Las horas solitarias (1918), $O C, \mathrm{~V}, 365]$; y en sus Memorias reconoce la existencia en el seno de la familia de «un fondo de rivalidad oscura de índole animal, más aún entre las personas del mismo sexo» (OC, VII, 538). Julio Caro Baroja, por su parte, al evocar a su abuelo y su tío maternos, ha recordado que «entre el optimismo sistemático del padre y la crítica implacable del hijo tercero, no podía haber conciliación " ${ }^{30}$; y también que:

Las diferencias en la concepción de la vida entre padre e hijos arrancaban de la época en que éstos eran jóvenes, casi adolescentes.

continuación cómo algunos de estos amigos propusieron a su padre entrar en un negocio con «unas proposiciones tan usurarias, tan bárbaramente judías que yo me quedé espantadon $(O C, \mathrm{~V}, 201)$. Y en las Memorias leemos: «Tenía mi padre tal fe en sus amigos de San Sebastián y en su pueblo, que vivió siempre con una ilusión completamente absurda. Creía que eran gentes especiales, distintas a los demás; pero, en el fondo, eran unos arrivistas que iban a lo suyo y no tenían la menor idea de ayudarle a él. Cuando llego el momento en que necesitó de su apoyo, yo pude ver que su amistad era falsa y se perdía en la vana palabrería (OC, VII, 523). Y Julio Caro ha recordado por su parte «la antipatía que le producfan [a su tío] la mayoría de los camaradas de su padre, incluidos los amigos de la infancia, que le parecían hombres muy distintos a los que veía su padre mismo con ojos favorables» (Julio CaRo Baroja, op. cit., p. 43).

30 Julio Caro Baroja, op. cil., p. 44. 
Serafín Baroja no había sido un rebelde de estudiante. Sus hijos lo fueron.

La mezcla de capacidad discursiva y de crítica, con la falta de éxito en los estudios de su hijo Pío, debió causarle zozobra y parece -por lo que yo he oído después a algunos ingenieros viejos-que, en sus tertulias profesionales, había hablado alguna vez de este hijo con algo de sorna, llamándole «el genio». Si ello llegó a oídos de mi tío, que de joven y aún de viejo era hipersensible, no cabe duda de que hubo de herirle bastante ${ }^{31}$.

Si nos fijamos ahora en la figura materna que Baroja ha diseñado en El árbol de la ciencia, y la comparamos con la imagen de doña Carmen Nessi que nuestro autor ha trazado en sus Memorias, también observamos coincidencias evidentes entre ambos retratos ${ }^{32}$ :

Su mujer, Fermina Iturrioz, fue una víctima [leemos en El árbol a propósito de la madre de Andrés]; pasó la existencia creyendo que sufrir era el destino natural de la mujer (OC, II, 452).

Y en sus Memorias, don Pío nos recuerda que su madre «tenía un fondo de renunciación y fatalismo», y que:

Para ella, evidentemente, la vida era algo serio, lleno de deberes y de poca alegría. Tenía una idea muy severa del deber; yo sospeché siempre que no tenía esperanza ninguna.

Mi madre trabajó durante toda su vida, sin salir apenas de casa, sin ir a paseos ni a teatros, acostándose tarde y levantándose temprano (OC, VII, 525).

Junto a este espíritu de sacrificio, resignado y fatalista, destaca en ambos textos el extremado rigor religioso de la madre, y su estricto puritanismo ético, presentado con un sesgo claramente hiperbólico en las páginas de $E l$ árbol, y en un tono más moderado en las Memorias:

\footnotetext{
31 Ibid., p. 43.

32 Véase Isabel Criado Mrguel, op. cit., pp. 36 y ss., y 106 y ss.
} 
La madre de Andrés, navarra fanática, había llevado a los nueve o diez años a sus hijos a confesarse.

Esta primera confesión fue para él un chorro de agua fría $(O C$, II, 452-53).

La madre de Baroja, por su parte, según reconoce el autor en sus Memorias, «tenía una moral un tanto rígida» ( $O C$, VII, 639), con «algo de mujer educada en un ambiente protestante y puritano» ( $O C$, VII, 525). Su nieto Julio recuerda que doña Carmen Nessi «era una mujer religiosa, pero poco clerical» ${ }^{33}$, «de una bondad radical, envuelta en cierta severidad o puritanismo un poco pesimista» ${ }^{34}$; y en las primeras páginas del libro confiesa:

Creo, por ejemplo, que el puritanismo o algo parecido me viene impuesto por mi abuela materna... y que, en realidad, por temperamento heredado de mi padre yo no debía de ser un puritano ${ }^{35}$.

Y más adelante añade:

...su moral rigorista le prohibía hacer comentarios concretos acerca de vidas ajenas. Siempre había sido así, pero con la vejez la tendencia puritana se le exageró y hubo de privarse de las pocas distracciones que le habían atraído ${ }^{36}$.

Es probable, de otro lado, que el carácter retraído y la inhibición de Baroja frente al otro sexo engrandecieran ante sus ojos, con el transcurso de los años, la figura de doña Carmen Nessi, afianzando así el único vínculo afectivo con que el hijo pudo contar en los años de su madure ${ }^{37}$. No es de extrañar, por tan-

33 Juluo Caro Baroja, op. cit., p. 41.

34 Ibid., p. 50.

35 Ibid., p. 25.

36 lbid., p. 91.

37 «Desde el punto de vista del afecto por uno u otro de los ascendiente, se podrían dividir los hombres en patemales y maternales" (Las horas solitarias, $O C, \mathrm{~V}, 365$ ). "Yo siempre he sido de estos tipos maternales que se sienten más unidos a la madre que al padre. Esto Freud lo explica de una manera fantástica, suponiendo una rivalidad amorosa del chico con su padre -el complejo de Edipo-, lo que me parece una explicación un poco de mala literatura (Familia, infancia, OC, VII, 538). «El amor rayano en idolatria que tenía mi tío Pío por su madre y el haber vivido los dos juntos hasta que ella murio, a los ochenta y seis años, hicieron que en la vejez el hijo menor y ella se sintieran más unidos que antes» (Julio Caro Baroja, op. cit., p. 50). 
to, que el dolor y la desolación de algunos personajes barojianos sean consecuencia inmediata de la falta de ese lazo sentimental, como ocurre a Andrés Hurtado, a quien «La muerte de su madre le había dejado un gran vacío en el alma y una inclinación por la tristeza» $(O C, \mathrm{II}, 451)$.

El círculo de amistades con el que se relaciona el joven Hurtado, coincidente en todo con el del propio autor, es otro dato importante a tener en cuenta a la hora de analizar y comparar la personalidad de Baroja y la del protagonista de su novela: Si damos fe a las primeras páginas de $E l$ árbol (OC, II, 449), la antipatía que nuestro autor sentía por su condiscípulo Riudavets (Montaner en la novela), debí de ser profunda y recíproca, al menos en el primer año de la carrera; y en cuanto a Julio Aracil, trasunto de un colega de Baroja, Carlos Venero, su figura aparece plasmada en $E l$ árbol de la ciencia con las tintas más negras, apenas suavizadas más tarde en las páginas de las Memorias, a diferencia de lo que ocurre con el entorno familiar:

Aracil había formado a su alrededor una camarilla de amigos a quienes dominaba y mortificaba [escribe Baroja en $E l$ árbol], y entre éstos se contaba Massó; le daba grandes plantones, se burlaba de él, lo tenía como un payaso.

Aracil demostraba una crueldad desdeñosa, sin brutalidad, de un carácter femenino (OC, II, 458).

Mientras que en las Memorias sólo apunta lo siguiente:

Mi condiscípulo Carlos Venero se sentía muy social, y quería dominar y aprovecharse de los demás. Esto le parecía lícito y lo conseguía (OC, VII, 584).

En ambos textos el autor explica en cambio, y ahora ya sin ninguna reserva, que:

Aracil era un poco petulante: se cuidaba el pelo, el bigote, las uñas y le gustaba echárselas de guapo. Su gran deseo en el fondo era dominar, pero no podía ejercer su dominación en una zona extensa, ni trazarse un plan, y toda su voluntad de poder y toda su habilidad se empleaba en cosas pequeñas ( $O C$, II, 462 y VII, 571). 
En fin, el tercer jalón importante en el proceso de formación de nuestro autor, es sin duda su temprano desengaño y su sentimiento de fracaso como profesional de la medicina, en las aulas universitarias primero, en el breve y decepcionante contacto con la práctica clínica después; y en este terreno, la similitud entre las vivencias de Baroja y las de Hurtado no ofrece la menor duda, según se deduce al cotejar las páginas de El árbol con las de Familia, infancia $y$ juventud o con las de otros textos autobiográficos anteriores:

«La ciencia es la única construcción fuerte de la Humanidad», afirma el protagonista de $E l$ árbol (OC, II, 510), igual que lo hará su creador en numerosas ocasiones $^{38}$. Sin embargo, los primeros contactos del joven estudiante con la enseñanza y la investigación científica constituyen un conjunto de experiencias a cual más decepcionante, y acrecientan el sentimiento de frustración, y la desconfianza respecto a la instituciones académicas y a las posibilidades de formación científica que el país le ofrecía ${ }^{39}$. Ya en las primeras páginas de la novela, por ejemplo, lo primero que Baroja recuerda, con palabras que luego reproducirá en sus Memorias, es el desalentador espectáculo que ofrecía la clase de Química:

Todo aquello era demasiado absurdo. Él hubiese querido encontrar una disciplina fuerte y al mismo tiempo afectuosa, y se encontraba con una clase grotesca, en que los alumnos se burlaban del profesor. Su preparación para la ciencia no podía ser más desdichada $(O C$, II, 451 y VII, 579).

Y recordando experiencias similares a las que incluyó en su novela, el propio autor reconoce en las páginas de Juventud egolatría (1917):

38 Ya en el Manifiesto regeneracionista de 1901, firmado con Azorín y Maeztu, los tres autores consideran que «este mejoramiento [social] sólo lo puede dar la ciencia, única base inderruible de la humanidad» (Plo BAROJA, Escritos de juventud, edic. cit., p. 373); y treinta años más tarde, fiel a sus ideas, nuestro autor volvía a afirmar en sus Intermedios (1931): «No se comprende que lo único revolucionario de verdad es la ciencia; lo demás es retórica, palabrería política, casi siempre hueca» $(O C, \mathrm{~V}, 704)$. Véase también, a proposito de este tema, Teresa GUERRA DE Gloss, op. cit., pp. 73 y ss.; y E. H. TEMPLIN, «Pío Baroja and Science», Hispanic Review, XV, 1947, pp. 165-192, especialmente pp. 186 y ss.

39 Para la actitud de Baroja ante la enseñanza y la ciencia en España, véase IgNAcio ElizAL. DE, Personajes y temas barojianos, Bilbao, Universidad de Deusto, 2.' edic., 1986, pp. 67 y ss.; GERARDo Ebanks, La España de Baroja, Madrid, Ediciones Cultura Hispánica, 1974, pp. 223 y ss.; y Félix Bello VAzquez, El pensamiento social y polftico de Pto Baroja, Salamanca, Universidad de Salamanca, 1990, pp. 233 y ss. La decepción que sufrí6 Baroja durante sus años de Universidad y en la práctica de la profesión, y la sensación de fracaso consiguiente, ha sido anotada y comentada por IsABel CRIADo MigUEL, op. cit., pp. 151 y ss., y 313 y ss. 
Yo no recuerdo de ningún profesor que supiera enseñar, que llegara a comunicar afición a lo que enseñaba y que tuviera alguna comprensión del espíritu del estudiante. En la Facultad, en mi tiempo, no se aprendía a discurrir, ni se aprendía a ser un técnico, ni se aprendía a ser un practicón. Es decir, no se aprendía nada $(O C, \mathrm{~V}, 197)$.

Más adelante, durante el cuarto curso, Andrés muestra cierto interés por el estudio de la Fisiología, ya que:

...creía que el estudio de las funciones de la vida le interesaría tanto o más que una novela; pero se engañó, no fue así. Primeramente, el libro de texto era un libro estúpido, hecho con recortes de obras francesas y escrito sin claridad y sin entusiasmo; leyéndolo no se podía formar una idea clara del mecanismo de la vida; el hombre parecía, según el autor, como un armario con una serie de aparatos dentro, completamente separados los unos de los otros, como los negociados de un ministerio.

Luego, el catedrático era un hombre sin ninguna afición a lo que explicaba, un señor senador, de esos latosos, que se pasaba las tardes en el Senado discutiendo tonterías y provocando el sueño de los abuelos de la patria (OC, II, 461).

Y en La formación psicológica de un escritor, discurso de ingreso en la Real Academia, incluido después en sus Rapsodias (1936), leemos:

Cuando cursaba Medicina sentía una vaga afición a la Fisiología: no sé si esta afición la hubiera podido desarrollar y conseguir que fructificase. De todos modos, no tuve medios de ver si mi afición podía desarrollarse o no. ¿A quién dirigirse? (OC, $\mathrm{V}, 875)$.

Y en cuanto a la posible vocación de Hurtado y Baroja por la investigación, las coincidencias entre la ficción novelesca y el relato autobiográfico son también evidentes:

- Si pudiera entrar en un laboratorio de Fisiología, creo que trabajaría con entusiasmo [explica Hurtado a su tío Iturrioz].

- ¡En un laboratorio de Fisiología! ¡Si los hubiera en España!

- ¡Ah, claro, si los hubiera! Además, no tengo preparación científica. Se estudia de mala manera. 
-En mi tiempo pasaba lo mismo - dijo Iturrioz-. Los profesores no sirven más que para el embrutecimiento metódico de la juventud estudiosa (OC, II, 506-7).

Y en el primer volumen de las Memorias, titulado El escritor según él y según los críticos, se lee:

Quizá si hubiese encontrado posibilidad me hubiera gustado intentar meterme dentro de una tarea científica en la juventud, aunque fuera oscura; pero no encontré ocasión ni la menor ayuda $(O C$, VII, 484).

El fracaso profesional del joven Baroja se inscribe además en un contexto más amplio que es preciso tener presente: el marasmo político y el desfallecimiento moral, la rutina y la indolencia, que dan la tónica de esa España finisecular, y que explican, en última instancia, las frustraciones y los sinsabores de Andrés Hurtado y de su creador ${ }^{40}$.

El estudiante culto, aunque quisiera ver las cosas dentro de la realidad e intentara adquirir idea clara de su país y del papel que representaba en el mundo, no podía [leemos en El árbol y en las Memorias]. La acción de la cultura europea en España era realmente restringida y localizada a cuestiones técnicas; los periódicos daban una idea incompleta de todo; la tendencia general era hacer creer que lo grande de España podía ser pequeño fuera de ella, y al contrario, por una especie de mala fe internacional (OC, II, 450 y VII, 574).

Es esa «tendencia natural a la mentira, a la ilusión del país pobre que se aísla», continúa el autor, la que «contribuía al estancamiento, a la fosilización de las ideas», y la que fomentaba el «ambiente de inmoralidad, de falsedad» que se manifestaba en las cátedras (OC, II, 450 y VII, 574-78). Y años más tarde, en su ensayo titulado Divagaciones apasionadas (1924), el escritor ya maduro se queja, volviendo de nuevo la vista al pasado:

40 La presencia recurrente del problema de España en la obra barojiana ha sido estudiada, entre otros, por IgNacio Elizalde, op. cit., pp. 53 y ss., y especialmente por Félix Bello VAZQUEZ, op. cit., pp. 191-348. 
El segundo período de mi vida, ya en plena juventud, se deslizó en Madrid, donde uno pudo observar cómo toda la vida española se iba desmoronando por incuria, por torpeza y por inmoralidad $(O C, \mathrm{~V}$, 492).

El vacío sentimental de un lado, y la falta de seguridad en la infancia y la juventud, junto al fracaso vocacional y la contemplación de una sociedad que se desmorona, modelan ya desde el principio el carácter del joven Pío con sus perfiles más típicos: espíritu reconcentrado y solitario, tristeza y misantropía, tendencia al aislamiento. En El árbol vemos cómo Andrés Hurtado, que pronto ocupará un cuarto separado del resto de la casa $(O C$, II, 455), experimenta «la sensación de sentirse solo y abandonado" $(O C$, II, 451$)$ :

Se sentfa aislado de la familia, sin madre, muy solo, y la soledad le hizo reconcentrado y triste. No le gustaba ir a los paseos donde hubiera gente, como a su hermano Pedro; prefería meterse en su cuarto y leer novelas $(O C, \mathrm{II}, 453)$.

Y más adelante, durante su estancia en Valencia:

Andrés no quería salir a la calle; sentía una insociabilidad intensa. Le parecía una fatiga tener que conocer a nueva gente.

Andar por las calles le fastidiaba, y el campo de los alrededores de Valencia, a pesar de su fertilidad, no le gustaba (OC, II, 503).

Además, Andrés se siente como un extraño en el mundo que le rodea, y «distinto cuando hablaba con sus condiscípulos en los pasillos de San Carlos y cuando soñaba en la soledad de su cuartucho» (OC, II, 459), y de ahí que simpatice con Antonio Lamela, un soñador enamorado de una mujer horrible a la que él ha idealizado, ya que «los dos tenían una vida interior distinta al resto de los estudiantes» $(O C, \mathrm{II}, 467)$.

Todas estas afirmaciones se repiten en textos posteriores de carácter autobiográfico, si bien el escritor las suaviza, y achaca su carácter reconcentrado a los frecuentes cambios de residencia que hubo de sufrir durante sus primeros años, al clima o a sus escasas amistades. Así, nuestro autor reconoce que en su adolescencia se sintió "muy abandonado, muy desvalido» $(O C, \mathrm{VII}, 562)$, ya que: 
Al cambiar del sitio donde se vive, sobre todo en la infancia, se cambia también de amigos. Todo ello, con los años, va empujando al aislamiento y se tiende a sentirse entre la gente un solitario, si no como un verdadero Robinson en una isla desierta, como un falso Robinson en el árbol de cuco $(O C \text {, VII, 560 })^{41}$

En Juventud, egolatría, recordando su etapa valenciana, nos explica que, igual que ocurrió a Andrés Hurtado:

Como no conocía a nadie, no salía de casa, ni iba a ninguna parte; me pasaba los días tendido en el terrado y leyendo $(O C, \mathrm{~V}, 199)$.

Y en las Memorias, matizando las palabras que había usado en El árbol, recuerda que en aquel período:

Pasados los primeros meses, en que yo salí algo de casa, me dio por recluirme. El calor suele ser para mí, en general, deprimente, y sentía una insociabilidad profunda.

Andar por las calles me fastidiaba, y el campo de los alrededores de Valencia, a pesar de su fertilidad, no me gustaba $(O C$, VII, 601).

Sin embargo, el autor reconoce en sus Rapsodias (1936) que fue en la época de estudiante cuando él y otros:

41 Luis Murguía, protagonista de La sensualidad pervertida y trasunto del propio Baroja, recuerda: «La infancia la pasé en varios pueblos. Mi padre, militar por un capricho de su juventud, no tenía ningún amor por la milicia. Era un espíritu turbulento e inquieto. Una de las manifestaciones de su inquietud la constituía el afán de cambiar de pueblos, y en cada pueblo cambiar de casas. Aquella manía se la comunicó a mi madre, y los dos se pasaban la vida proyectando traslados que les desilusionaban en seguida. Por la manía ambulatoria de mis padres, mi infancia fue una serie de viajes por las ciudades españolas y una serie de mudanzas.

De chico, tales mudanzas y traslados me parecían una cosa muy divertida; luego, no sé a punto fijo por qué, me han dejado un recuerdo triste.

Todas las circunstancias de mi vida han tendido a hacerme un hombre aislado, disgregado, separado del rebañon (OC, II, 849-50 y 857-58). 
...naturalmente cándidos y bienintencionados de chicos, nos hemos ido agriando y haciéndonos esquinudos y atravesados con el trato social y con la vida $(O C, \mathrm{~V}, 875)$.

Años más tarde, en su época de panadero, sintiéndose cada vez más desconectado del medio, experimentaba «la sensación de ser un extranjero ignorante del idioma que hablaba la gente de al lado» $(O C$, VII, 651); y al evocar los últimos años del siglo, en que hubo de aceptar su condición de médico fracasado e industrial sin éxito, recuerda que:

En tiempos así, en que el fracaso se cierne, sobre una persona, el hombre inadaptado tiende a replegarse sobre sí mismo y a separarse de los demás en ideas prácticas y teóricas (OC, VII, 684).

Consideraciones, todas ellas, que coinciden con el juicio de Julio Caro, quien ha evocado con estas palabras el carácter de su madre, y por contraste, el del resto de la familia:

En conjunto siempre tomaba la postura más sociable. Pero le valía de poco, porque en casa los hombres estaban (estábamos puedo decir a partir de una fecha) en franca oposición con el medio. Se convirtí, al fin, en un nido de aves solitarias o por lo menos de las que no gustan de ir en bandadas ${ }^{42}$.

Y respecto a su tío, comenta que, a pesar de haberse vuelto más sociable y tranquilo con el paso de los años:

...de joven, sí, había sido muy huraño, áspero e insociable. Era la época, sin duda, en que su personalidad como literato tenía que desenvolverse y en la que todo son luchas internas y externas. Lucha con la gente de alrededor, obsequiosa y servil con las personalidades consagradas y cruel con el joven orgulloso; lucha con las propias inexperiencias, ignorancias, lagunas, con los descorazonamientos prematuros, con las ilusiones excesivas, con los rivales ${ }^{43}$.

42 Julio Caro Baroja, op. cit., p. 64.

43 Ibld., pp. 69-70. 
En ese distanciamiento hostil con respecto al entorno, similar al del protagonista de $E l$ árbol, debemos buscar el origen de la extremada sensibilidad de nuestro autor y de su especial clarividencia para percibir el dolor, la injusticia y el mal. Esta hiperestesia no es, sin embargo, ninguna fuente de felicidad, ya que el hombre, pensaba Baroja, necesita la sensibilidad justa para vivir sano y tranquilo: si tiene menos, será como un niño; si tiene más, vivirá como un enfermo (Juventud, egolatría, $O C, \mathrm{~V}, 165$ ); y así, a Hurtado, igual que a su creador:

El mundo le parecía una mezcla de manicomio y de hospital; ser inteligente constituía una desgracia, y sólo la felicidad podía venir de la inconsciencia de la locura (OC, II, 469 y VII, 596) ${ }^{44}$.

La consecuencia más inmediata y evidente de tales sentimientos es el proverbial y rotundo pesimismo de nuestro autor ${ }^{45}$, trasladado con pocas variaciones al alma del personaje. Así:

44 La idea de que la sensibilidad y la inteligencia son enemigas de la felicidad -el árbol de la ciencia frente al árbol de la vida-, es otro leit-motiv presente en la novela que comentamos y en toda la obra de Baroja. Así, ya en el artículo titulado «Melancolfa», publicado en La Justicia (23 de diciembre de 1893), se nos recuerda, parafraseando al Eclesiastés, «que en la mucha sabiduría hay mucha molestia, y que quien añade ciencia añade dolor. No, mi sabiduría no mitigó mis vagos anhelos» (Plo Baroja, Escritos de juventud, edic. cit., p. 62). En su tesis doctoral sobre el dolor, redactada en esta misma época, Baroja habra expresado opiniones semejantes, según ha recordado Juan Pedro Maguna («La estética del dolor en Pio Baroja», Letras de Deusto, II, n. ${ }^{2} 4$, jul-dic. 1972, pp. 139-169). La misma idea aparece en «Parábola», uno de los cuentos incluidos en Vidas sombrias: «y estudié en Egipto, y en Babilonia, y en Persia, y en Caldea, y medí la distancia de los astros y calcule las alturas del sol. Y vi que en la mucha sabiduria hay mucha molestia y que quien añade ciencia añade dolor» $(O C, \mathrm{VI}, 994)$. En La feria de los discretos, uno de los personajes explica que $\ll E l$ saber es el enemigo de la felicidad. Ese estado de paz, de sosiego, que los griegos llamaban, con relación al organismo, euforia, y con relación al alma, ataraxia, no se puede obtener más que no conociendo* (OC, I, 742-43). Y todavía en las Rapsodias (1936): «La vida es como un viaje de funámbulo en la cuerda floja y sobre el abismo insondable. Tiene sentido cuando se rige por el instinto y por la pasión. Cuando pretende ser completamente consciente es cuando comienza a parecer rota, inconexa, contradictoria y hasta cómica. Hecho tan viejo está representado en la $B i$ blia por el simbolismo del árbol de la vida y el árbol de la ciencia y por la frase del Eclesiastés: "Quien añade ciencia añade dolor"» $(O C, \mathrm{~V}, 869)$.

45 «Pío Baroja es un pesimista irreductible [ha escrito Azorín a propósito de su compañero de generación]. Tal vez de la lectura de sus libros surge angustiosa la sensación de que nuestra vida no tiene finalidad alguna y de que la felicidad, que creemos existe, es un vano fantasman (AzORíN, $o p$. cit., p. 38). Entre las numerosas referencias bibliográficas referentes al tema, vale la pena recordar las aportaciones de LuIS S. GRANJEL op. cit., pp. 267 y ss.; EDITH R. ROGERS, «Sobre el pesimismo de Barojaw, Hispania, XLV, 1962, pp. 671-674; CARMEn Iglesias, El pensamiento de Pio Baroja. Ideas centrales, México, Antigua Librería Robredo, 1963, pp. 32 y ss.; TeRESA GUERRA DE Gloss, op. cit., pp. 40 y ss.; y Félix Bello Vazquez, op. cit., pp. 20 y ss. 
Fuera de aquellos momentos [los que Hurtado pasa junto a algún compañero], en los demás, el estudio, las dicusiones, la casa, los amigos, sus correrías, todo esto mezclado con sus pensamientos, le daba una impresión de dolor, de amargura en el espíritu. La vida en general, y sobre todo la suya, le parecía una cosa fea, turbia, dolorosa e indominable $(O C$, II, 460$)$.

Más adelante, tras el paso por San Juan de Dios, leemos en El árbol y en las Memorias:

La inacción, la sospecha de la inanidad y de la impureza de todo, arrastraban a Hurtado cada vez más a sentirse pesimista.

Pensaba que en la vida ni había ni podía haber justicia. La vida era una corriente tumultuosa $\mathrm{e}$ inconsciente, donde todos los actores representaban una comedia que no comprendían; y los hombres, llegados a un estado de intelectualidad, contemplaban la escena con una mirada compasiva y piadosa (OC, II, 471 y VII, 598).

Y qué duda cabe que todo ello refleja de manera exacta el sentir del joven Pío, perplejo ante una existencia cuyos dolorosos enigmas intenta descifrar infructuosamente en los escritos de Schopenhauer, al que pronto sigue y admira $^{46}$ :

La visita en San Juan de Dios fue un nuevo motivo de depresión y melancolía para Hurtado [se lee en El árbol y en las Memorias]. Pensaba que por una causa o por otra el mundo le iba presentando su cara más fea. A los pocos días de frecuentar el hospital, Andrés se inclinaba a creer que el pesimismo de Schopenhauer era una verdad casi matemática (OC, II, 469 y VII, 596).

Se trata, en efecto, de un pesimismo absoluto, proclamado de manera concluyente en numerosos textos posteriores, y que alcanza, igual que en Hurtado, tanto al sentido de la existencia humana —No creo que la vida tenga objeto

46 Cfr. el artículo de E. INMAN Fox, «Baroja y Schopenhauer. El árbol de la ciencia», en Pio Baroja, edic. de Javier Martínez Palacio, Madrid, Taurus, El escritor y la critica, 1974, pp. 397 408. 
fuera de sí misma», se lee en las Memorias (OC, VII, 484) ${ }^{47}$, o al origen y destino del mundo - «una bola fantástica, repleta de carne enferma y dolorida, que anda paseándose por los espacios» ( $O C$, VII, 683)—, como a la moral y la conducta del hombre, que «no ha variado desde las épocas antiguas acá», y sigue siendo «el animal astuto, cruel, cobarde y sanguinario que ha sido siempre» $(O C, \mathrm{VII}, 831)^{48}$.

Si pasamos a examinar la segunda parte de la obra, titulada «Las carnarias», nos encontramos con una galería pintoresca de tipos de la época, que oscilan entre la extravagancia y la ruindad, y que además de corresponder probablemente a tipos reales ${ }^{49}$, sirven para dar cuerpo a esa concepción negativa del hombre a la que acabamos de aludir ${ }^{50}$. Lo que hallamos en esas páginas es, en efecto, una imagen darwiniana de la existencia: los seres humanos, igual que los protozoos y las alimañas, vivimos inmersos en «una lucha constante, una cacería cruel en que nos vamos devorando los unos a los otros. Plantas, microbios, animales», comenta Iturrioz a propósito de los tipos que han ido apare-

47 «En su vejez mi tío tuvo una sensación mayor que nunca de que la vida no tiene objeto, ni fin concreto, que el hombre es como un barco mal gobemado en un mar tempestuoso y que nada valía la pena de tantas luchas y maldades» (Jullo CARo BAROJA, op. cit., p. 79).

48 Cfr. también: «La vida es esto: crueldad, ingratitud, inconsciencia, desdén de la fuerza por la debilidad, y así son los hombres y las mujeres, y así somos todos» (El mundo es ansi, OC, II, 842). «El homo sapiens, que no es casi nunca sapiente, es un animal falso, cruel, hipocrita, sanguinario, cobarde* (Pequeños ensayos, $O C, \mathrm{~V}, 1035$ ). Al rebatir a quienes le consideran un anarquista térico, nuestro autor afirma que él no tiene fe en el hombre, sino que, «por el contrario, por instinto y por experiencia, creo que el hombre es un animal dañino, envidioso, cruel, pérfido, lleno de malas pasiones, sobre todo de egoísmos y de vanidades» (El escritor según él y según los críticos, $O C$, VII, 414). «Es evidente que la mayoria de los hombres y de las mujeres aplastarian, arrastrarian y despedazarian, si pudieran, a su rival. Casi todos tenemos un fondo de saña, de egoísmo, de venganza, más o menos oculto, más o menos paliado» (La intuición y el estilo, $O C$, VII, 984).

49 «Tipos bastante absurdos conocí en esta época, que la mayoría fueron apareciendo, más o menos caricaturizados, en mis libros [explica el autor en el cuarto volumen de sus Memorias, titulado Galería de tipos de la época].

Algunos me han solido preguntar: inventa?

- Existen en España esos tipos extravagantes, de los que usted habla en sus novelas, o los

-No sé si existen aún; pero, al menos, han existido» (OC, VII, 951-52).

50 No obstante, recordando tal vez a los modelos reales de esta segunda parte del libro, el autor había escrito ya en una de las narraciones de Vidas sombrias: «Salí del café, pensativo. El comico, el de la funeraria, el prestamista, el general, el cura, todos me parecían sin conciencia, y, además de éstos, el abogado que engaña, el comerciante que roba, el industrial que falsifica, el periodista que se vende, y..., sin embargo, pensé después: toda esta tropa que roba, que explota, que engaña y que prostituye tiene sus rasgos buenos, sus momentos de abnegación y sus arranques caritativos. La verdad es que, semiángel o semibestia, el hombre es un animal extraño» $(O C, \mathrm{VI}$, 1020). 
ciendo en esta segunda parte $(O C, \mathrm{II}, 492)$. De esta forma, «se encuentran en el hombre todas las formas de la explotación y de la lucha: la del microbio, la del insecto, la de la fiera» $(O C, \mathrm{II}, 493)^{51}$, y por consiguiente, concluye el tío de Hurtado:

La justicia es una ilusión humana; en el fondo, todo es destruir, todo es crear. Cazar, guerrear, digerir, respirar, son las formas de creación y de destrucción al mismo tiempo (OC, II, 494).

De entre los personajes que desfilan a lo largo de esta segunda parte del libro, destaca sobre todo Lulú, trasunto de una joven a la que Baroja conoció en sus años de estudiante, y a la que recordará en el último volumen de sus Memorias, titulado Bagatelas de otoño, con las mismas palabras que había utilizado años antes en las páginas de El árbol: una joven graciosa, de ojos verdes, ojeras negruzcas, frente pequeña, boca de labios finos, y cara pálida, de mal color $(O C$, II, 475 y VII, 1324).

Sin embargo, más que las concomitancias entre la Lulú real y su versión literaria, lo que sobresale en este personaje, y lo que nos interesa destacar con vistas a descubrir el auténtico trasfondo autobiográfico de la novela, son sus cualidades morales e intelectuales, y la forma en que Baroja expresa a través de los episodios por ella protagonizados, algunas de sus ideas acerca del matrimonio, la mujer y las relaciones entre los sexos ${ }^{52}$.

Señalemos, ante todo, que Lulú es «una mujer inteligente, cerebral», por la que Hurtado sólo siente al principio «una cordial amistad», y que la conversación que tuvo en el baile con ella, despertó en Andrés «el deseo de intimar algo más con la muchacha» (OC, II, 481-82); y en Las horas solitarias, volumen de artículos y reflexiones publicado en 1918, es el propio autor quien confiesa:

Para mí lo principal en una mujer es que tenga encanto su charla. Lo demás casi no me importa. El diálogo, eso me parece lo trascendental $(O C, \mathrm{~V}, 247)$.

51 «Todos los animales, y el hombre no es más que uno de ellos, se encuentran en un estado permanente de lucha; el alimento tuyo, tu mujer, tu gloria, tú se lo disputas a los demás; ellos te lo disputan a ti» (Aurora roja, OC, I, 635). «Porque la vida no es un idilio, ni mucho menos. Vivimos matando, destruyendo todo lo que hay a nuestro alrededor, llegamos a ser algo deshaciéndonos de nuestros enemigos. Estamos en continua lucha» (César o nada, OC, II, 578).

52 Véase acerca de este tema Isabel. CRIADO Miguel, op. cit., pp. 218 y ss., y 236-37. 
Todo lo cual parece situarnos ante un Baroja maduro, inseguro y retraído frente al otro sexo, y quizá desengañado respecto al brillo externo y la superficialidad de algunas mujeres exageradamente atractivas.

Más adelante, tras el matrimonio, las cualidades que más admira Andrés en su esposa son «aquellas condiciones de arreglo, de orden y de economía de Lulú» $(O C, \mathrm{II}, 564)$; las mismas que Baroja hubiera deseado en la compañera que nunca llegó a tener, ya que, según explica en el conjunto de ensayos titulado Tres generaciones:

La mujer y el amor son una obsesión para el hombre de este tiempo; la mujer tiene gran importancia, porque se espera de ella un reforzamiento espiritual. Esta mujer, que se supone que puede dar un equilibrio psicológico, es la mujer humilde, la mujer sin brillo, la mujer del hogar $(O C, \mathrm{~V}, 576)$.

Recordemos, en fin, que Baroja ha planteado más de una vez, y de forma valiente, lo que él mismo denominó en las páginas de Juventud, egolatría, «La tragicomedia sexual», y que en esencia consiste en lo siguiente: «sumisión o desequilibrio», o, lo que es lo mismo, pasar «unos años de vida sexual extramuros, en los fosos de la prostitución», para someterse después a la servidumbre del matrimonio, «con el vasallaje a las normas sociales y a las categorías más absurdas»; 0 , de lo contrario, verse «irremisiblemente condenado al desequilibrio, a la enfermedad, a la histeria» $(O C, \mathrm{~V}, 170-71)^{53}$. Y en el tercer volumen de sus Memorias, titulado Final del siglo XIX y principios del XX, el autor vuelve a insistir:

Entre el tipo como yo, individualista acérrimo, que había absorbido los sueños de Dickens, de Ibsen, de Tolstoi, de Dostoyevski y de Paul Verlaine, y la mujer de familia, con un sentido tradicional y social, era imposible el buen acuerdo.

$\mathrm{La}$ insinuación constante del hombre rebelde de mi tiempo para la mujer que pretendía era decirle, con más o menos claridad: «Rompe

53 Cfr. las reflexiones similares de Luis Murguía, el protagonista de La sensualidad pervertida, acerca del dilema sexual: ${ }_{i}$ Cómo resolver esa cuestión? - pensaba - O O hay que tener dinero, y yo apenas lo tengo, o sumisión, cosa que me repugna. Todo está hecho a base de sumisión. ¿Quieres ganar? Hay que someterse. ¿Quieres vivir con una mujer? Hay que someterse. ¿Quieres tener sitio para respirar? Hay que someterse, y someterse a un sistema viejo, sin prestigio, absurdo, que quizá durante la propia vida de uno sea abandonado" $(O C, \mathrm{II}, 893)$. 
con el medio». La recomendación de la mujer, clara o velada, para su galanteador, que le parecía extravagante, era la contraria: «Acomódate al medion (OC, VII, 679).

El mismo dilema íntimo, y en idénticos términos, aparece planteado en las páginas de El árbol, especialmente durante la estancia de Andrés en Alcolea del campo:

Si quería vivir con una mujer, tenía que casarse, someterse. Es decir, dar por una cosa de la vida toda su independencia espiritual, resignarse a cumplir obligaciones y deberes sociales (OC, II, 535).

La Lulú de $E l$ árbol, en cambio, es la joven con la que un hombre inconformista como Hurtado, y como el propio Baroja, podría contraer matrimonio sin necesidad de someterse: una joven «acostumbrada a no guardar respeto a nada ni a nadie» $O C$, II, 483 ), y a la cual:

...no le parecía mal el adulterio, ni los vicios, ni las mayores enormidades; lo que le molestaba era la doblez, la hipocresía, la mala fe. Sentía un gran deseo de lealtad (OC, II, 484).

Antes de entrar a examinar la tercera parte de la novela, titulada «Tristezas y dolores», debemos recordar algunos hechos significativos en la trayectoria biográfica de nuestro autor ${ }^{54}$ : En 1892 , el padre de Baroja consigue una plaza de ingeniero jefe en Valencia y se trasladaba allí con toda su familia. En el otoño del mismo año, el hermano mayor de Baroja, Darío, empieza a mostrar síntomas de una tuberculosis en ciemes. Entre tanto, nuestro autor estudia con ahínco y consigue terminar la licenciatura entre junio y septiembre de 1893, para trasladarse después a Madrid con la idea de cursar las asignaturas de doctorado. En febrero de 1894 vuelve a Valencia, tras haber recibido noticias del grave estado de su hermano, que fallecerá al día siguiente de su llegada. El trágico desenlace de la enfermedad de Darío fue un golpe terrible para la familia, que decidió abandonar Valencia y alquilar una casa en Burjasot,

54 Véase, para esta etapa de la biografia de Baroja, el volumen de las Memorias dedicado a Familia, infancia, y juventud (OC, VII, 600-613); MigUel. Pérez FerRERo, op. cit., pp. 69-76; y KENNETH ELLER, art. cit., pp. 325-26. 
mientras Pío regresa a Madrid, donde concluye el doctorado en el verano de ese mismo año.

Los acontecimientos que acabamos de relatar se recogen en las páginas de El árbol con algunas variaciones sustanciales, destinadas sin duda a hacer más terrible la experiencia de la muerte, y más intensos el dolor y la desolación que su presencia acarrea: Luisito es un niño, muy unido a su hermano mayor, y con su enfermedad y su muerte, atrozmente agravadas por una meningitis tuberculosa, desaparece el vínculo más firme entre Andrés y su familia. En la novela es la enfermedad de Luisito la que motiva el traslado de los hermanos a Valencia, a una casa de campo próxima a la ciudad, propiedad de unos parientes. El viaje que Andrés realiza a Valencia para conocer la casa (OC, II, 496-97), aparece evocado con las mismas palabras en las Memorias: se trata del viaje de Baroja desde Madrid a Valencia tras haber recibido el telegrama en que se le anunciaba la muerte inminente de Darío (OC, VII, 608-9); y la casa de campo que los Hurtado ocuparon cerca de la ciudad ( $O C$, II, 497-99), es la misma que los Baroja alquilaron en Burjasot, y que el escritor volverá a evocar años más tarde en sus Memorias (OC, VII, 609-11).

En la cuarta parte de la novela reaparece Iturrioz, un personaje en el que nos parece ver retratado a Justo Goñi, primo carnal de doña Carmen Nessi, el cual compartió con sus sobrinos Pío y Ricardo muchas inquietudes intelectuales y una marcada inclinación a la vida bohemia, y en el que nuestro autor se inspiró para crear algún personaje, entre ellos, probablemente, al tío Andrés ${ }^{55}$. Iturrioz y Goñi tienen un carácter seco y egoísta en apariencia ${ }^{56}$; el primero era médico militar, y el segundo, médico también, había intentado ingresar en la Academia Militar ${ }^{57}$. En 1898 Baroja recibe noticias de la guerra de Cuba a tra-

55 En una entrevista publicada en La Estafeta Literaria, y reproducida después en Familia, infancia, Carmen Baroja señala: «Hay quien afirma que Iturrioz, de El árbol de la ciencia, tiene cierto parecido con un primo de nuestra madre, que nos visitaba con frecuencia; pero yo considero tan lejana la semejanza, que lo mismo puede ser verdad que no serlo» $(O C$, VII, 481). El hermano de Baroja, Ricardo, afirma, por su parte: «En las novelas de mi hermano aparecen frases de este magnífico tipo [se refiere a Justo Gonii], gloria y prez de nuestra familia* (RICARDO BAROJA, *El to Justo, filósofo positivista», en Gente de la generación del 98, Barcelona, Editorial Juventud, 2.' edic., 1969, p. 182); y Jul.o CARO B AROJA recuerda: «El primo Justo sale entre los personajes de mi tío (op. cit., p. 54).

56 \&No le importaban absolutamente nada las opiniones ajenas [explica el hermano del autor a proposito de Justo Goñi]. Forrado con su triple capa de egoísmo, toda conversación con mi pariente quedaba reducida a un monólogo, de él, por supuesto» (RICARDo BAROJA, op. cit., p. 183); y en $E l$ árbol leemos: "Al principio de conocerle - Andrés no le trató a su tio hasta los catorce o quince años-, Iturrioz le pareció un hombre seco y egoísta, que lo tomaba todo con indiferencia» (OC, II, 491).

57 «Le asistía un criado, antiguo soldado de la época en que Iturrioz fue médico militar» (OC, II, 491); y Justo Goñi «había empezado la carrera de ingeniero militar, pero no la acab6. Luego estudio la de abogado, que también dejó a medio acabar, y, por fin, se hizo médico* (OC, VII, 646). 
vés de su tío Justo, uno de cuyos hermanos, Antonio, era oficial de la Armada y estaba destinado en el Cristóbal Colón (OC, VII, 653); e Iturrioz, por su parte, había residido en Cuba (OC, II, 544), y a través de él conoce Hurtado las verdaderas proporciones del desastre que se avecina ( $O C$, II, 543). En fin, la exaltación del espíritu ibérico y vasco por parte de Iturrioz $(O C, \mathrm{II}, 517)$, coincide con la actitud de Justo Goñi, un «teórico del racismo vasco» ${ }^{58}$ muy orgulloso de su ascendencia ${ }^{59}$; mientras que la pasión de este último por la filosofía positivista ${ }^{60}$, queda plasmada en los consejos de Iturrioz a su sobrino, al que invita a seguir a los empiristas ingleses $(O C, \mathrm{II}, 507)$.

En la quinta parte de $E l$ árbol, titulada «La experiencia en el pueblo», Baroja vuelve a introducir en la trama de la novela significativas porciones de su propia experiencia vital, y concretamente el recuerdo de su traslado en agosto de 1894 a Cestona (Guipúzcoa), donde ejercerá como médico hasta septiembre del año siguiente. La novela, en efecto, recoge de forma muy directa algunas de las experiencias vividas en Cestona, ya que los mismos hechos vuelven a aparecer años después en las páginas de las Memorias narrados con idénticas palabras: así ocurre con la rivalidad entre el joven Pío y el otro médico del pueblo, Juan Sánchez en la novela y Pedro Díaz en la realidad; las dificultades de la profesión médica; las recomendaciones al paciente artrítico acerca del consumo de carne; y la curación de la joven aquejada de hidropesía, que agravó la hostilidad entre Baroja y su colega (OC, II, 522-27 y VII, 625-29) ${ }^{61}$. En otros casos es difícil discernir la realidad de la ficción, aunque no cabe duda de que en lo más hondo del espíritu de Baroja, Alcolea del Campo y Cestona tienen mucho en común:

El oficio de médico de aldea era entonces, y seguirá siendo ahora, difícil, mal pagado, trabajoso y de gran responsabilidad [escribe el

58 Julio Caro Baroja, op. cit., p. 54.

59 «Justo había nacido en Jerez; pero, a pesar de su nacimiento en Andalucía, mostraba gran entusiasmo por su origen vasco [...]. Tenía una preocupación étnica mucho antes de que se generalizaran las teorías de los antropologos racistas, y le preocupaban e intentaba aplicarlas a la vida [...]. También hablábamos de etnografía y de sociología. Salían a relucir iberos, celtas, germanos, etcétera (OC, VII, 645). «Si me quitan a mí lo bereber, ¿qué me queda? Lo vasco, ¿no es eso? [solía comentar Justo Goñi] Pues bien, siendo yo vasco, ¿por qué no me llevan a un museo antropologico y no me meten en una vitrina como ejemplar escogido de la humanidad?» (Ricardo Baroja, op. cit., p. 184).

60 «Hasta los treinta y cinco estudió mucho, devoró libros de filosofía» (Ricardo Baroja, op. cit., p. 182). «La filosofía positivista fue después motivo predilecto de sus desvelos» (Ibid., p. 184).

61 Acerca de esta etapa de la vida de don Pro, véase también Miguel Pérez Ferrero, op. cit., p. 76-82; y KENNETH ELLER, art. cit., pp. 330-32. 
autor en sus Rapsodias (1936)], La vida de médico de pueblo me parecio dura, aunque tenía ciertamente algunas compensaciones.

Tuve rivalidades con otro médico más antiguo, rivalidades que yo no sólo no las busqué, sino que las rehuí. En esto seguía la máxima de Gracián: no competir, que me parecía y me sigue pareciendo bien. La responsabilidad de tener una función demasiado importante, la falta de práctica y de conocimientos científicos completos, me hicieron pasar mala época (OC, $\mathrm{V}, 886-87)$.

Tales inconvenientes se vieron probablemente agravados en el caso del joven Baroja por la hostilidad que mostraron hacia él, además de su colega Díaz, otros vecinos de Cestona, según recordará en sus Memorias, cuando nos explica cómo:

Poco después de esto, cansado yo de la vida del pueblo, sórdida y llena de pequeñas rivalidades de profesión, dejé la plaza de médico de Cestona y fui a reunirme con mis padres a San Sebastián.

Al encontrarme sin empleo, pensé que los amigos de mi padre, a los que tanto ponderaba él, y que tenían tan gran influencia en San Sebastián, podrían hacer algo por mí e influir en que me dieran una colocación. Nada hicieron; por el contrario, dijeron que yo era un hombre de carácter insoportable. Uno de ellos, el señor Machinbarrena, personaje importante de la ciudad, afirmó que yo en Cestona, para llamar la atención, había disgustado al pueblo trabajando en la huerta de mi casa los domingos, para hacer ostentación de ideas antirreligiosas, y que me había peleado con todo el mundo (OC, VII, 634).

$Y$ aunque nuestro autor se apresura a desmentir las afirmaciones de los amigos de su padre ${ }^{62}$, confesará años después haber recibido a lo largo de su vida varios anónimos, gestados probablemente en las sacristías, y algunos de ellos durante su estancia en Cestona («Los anónimos», $O C, \mathrm{~V}, 1288$ ).

62 «No era cierto, no me habła peleado con nadie más que con el médico Diaz, que se había peleado conmigo y que luego siguió riñendo con todos los médicos que fueron al pueblo. Tampoco era verdad que trabajara en la huerta los domingos. La huerta de casa tenía una pared grande hacia la carretera, y desde ésta no se veía lo que se hacía dentro. Lo que es posible es que algún domingo, por la tarde, quemara algunas hierbas secas» (OC, VII, 635). 
Los datos que acabamos de exponer nos inducen a pensar que el paso de Andrés por Alcolea, igual que ocurre con las páginas iniciales dedicadas al retrato de familia, son un ajuste de cuentas del autor con su propio pasado, en el que se ha acentuado hasta la exasperación todo lo que hubo de negativo en el ejercicio de la medicina en el medio rural y entre los propios paisanos: De un lado, la vida «sórdida» de la aldea vasca que el autor ha evocado en sus Memorias, dominada por el tradicionalismo ultramontano ${ }^{63}$, es sustituida en las páginas de El árbol por la atmósfera mucho más asfixiante de Alcolea del Campo, una inexistente ciudad manchega en la que el autor, cargando las tintas, traza un desolador panorama del mundo rural de la época (OC, II, 527-28) ${ }^{64}$; mientras que en las difíciles relaciones de Baroja con los vecinos de Cestona y con el otro médico, debemos buscar los orígenes de la «mala reputación» de Andrés entre el pueblo - «se le consideraba hombre violento, orgulloso, mal intencionado, que se atraía la antipatía de todos», de la «hostilidad» entre ambos, y del odio intenso que el protagonista llega a experimentar hacia las gentes del lugar: «uno de esos odios profundos que llegan a dar serenidad al que lo siente; un desprecio épico y altivo" (OC, II, 534-36).

En las últimas páginas de esta quinta parte de la novela, la hostilidad del pueblo hacia el nuevo médico crece con motivo de un suceso violento, la muerte de la mujer del tío Garrota, durante cuyo esclarecimiento Hurtado se granjea la antipatía y la incomprensión de todos, pese a su actitud serena y sus juicios ecuánimes; y aunque el episodio no aparece reseñado en las $\mathrm{Me}$ morias, ni en otros textos autobiográficos, Baroja explica en los Intermedios (1931):

63 Señalemos, como botón de muestra, algunos testimonios del propio autor acerca de las gentes de Cestona: En las Memorias nos explica que Dolores, la Sacristana, en cuya casa se alojo Baroja, aunque gozaba de sus simpatías, era *muy entusiasta del tradicionalismo. Pertenecía a la rama más intransigente de esta tendencia, que entonces, y supongo que ahora, se llamaba integrista» (OC, VII, 614). Al aludir al balneario de Cestona, recuerda que «Los dueños eran carlistas. E] otro médico también lo era* (OC, VII, 621). Interesantes, sobre todo, son los comentarios de Baroja acerca de don León, un curioso personaje panteista y librepensador, que vivía en una localidad próxima (y probablemente similar) a Cestona, y que resistía «impávido, en el pueblo levítico dominado por reaccionarios» (OC, VII, 631-32). En 1918 nuestro autor advierte que los pueblos vascos «viven en plena teocracia, el cura interviene en todo. La gente cree que el párroco puede mandar, y como los alcaldes en general son pobres diablos, manda de hechon (Las horas solitarias, $O C, \mathrm{~V}$, 321). Y en La sensualidad pervertida comenta que La vida de Irín es una vida bastante alegre $y$ fácil; se gana y se gasta con facilidad; hay mucho forastero, mucho comisionista y no se siente tan fuertemente la presión de la iglesia como en los demás pueblos vascos. Por eso la gente no es tan hipocrita, ni tan solapada, ni tan tortuosa" (OC, II, 884).

64 Recuérdense las descripciones similares de Labraz (OC, I, 99-100), de Yécora en Camino de perfección (OC, VI, 91 y ss.), y de Castro Duro en César o nada (OC, II, 740-43), así como los comentarios de Féldx Bello Vázquez, op. cit., pp. 259-269. 
Yo, en el año y medio que estuve ejerciendo en Cestona, fui testigo de algún que otro drama rural intenso, que lo contaré en mejor ocasión $(O C, \mathrm{~V}, 678)$.

Sin embargo, los únicos sucesos dramáticos de esta época que Baroja recuerda, fueron protagonizados por un grupo de obreros forasteros a los que apodaban «los madrileños» (OC, VII, 620-23); y en las mismas páginas, igual que en las Memorias, nos aclara los motivos para no ser más explícito acerca de otros hechos similares, que debió conocer en su actividad profesional:

De algunas de esas cosas vistas no se puede hablar con libertad, porque, por mucho que se quiera disimular y despistar, sólo la indicación de la aldea ya basta para que se sepa en un pueblo de qué se trata y de quién se trata $(O C, \mathrm{~V}, 678$ y VII, 620).

En fin, el autor habrá de reconocer años más tarde, a propósito de su experiencia como médico de Cestona:

En la práctica de la medicina, en la aldea, se ven cosas muy extrañas, a veces terribles, que dan una impresión quizá demasiado viva del fondo de egoísmo y de brutalidad del hombre (OC, V, 678 y VII, 620).

Y así ocurre también en El árbol de la ciencia:

Andrés podía estudiar en Alcolea todas aquellas manifestaciones del árbol de la vida, y de la vida áspera manchega: la expansión del egoísmo, de la envidia, de la crueldad, del orgullo $\left(O C\right.$, II, 529) ${ }^{65}$.

65 «Desde el punto de vista moral, la gente del campo es, naturalmente, fanática, de espíritu cho y sin benevolencia [escribe nuestro autor en Las horas solitarias (1918), recordando tal experiencias propias]. El campesino ni tiene ni puede tener una moral suave y dulce; por el ario, es hombre de inquinas profundas, amigo del chisme y de la murmuración.

Suponer que el campesino puede ser amable, generoso, espiritual, es una cándida ilusión. El npesino es casi siempre egoísta, roñoso, malo y fanático» $(O C, \mathrm{~V}, 291)$. 
La soledad y la vida sedentaria hacen que Hurtado, durante su estancia en Alcolea, haya de plantearse el problema sexual en los mismos términos en que lo hizo Baroja al acercarse a la madurez: una vez rechazada la idea del matrimonio, y de la sumisión a las normas sociales que su aceptación supone, según vimos, Andrés ha de elegir entre acercarse a la ciénaga de la prostitución, o resignarse a convivir con el desequilibrio y la enfermedad:

De no casarse, Andrés podía transigir e ir con los perdidos del pueblo a casa de la Fulana o de la Zutana, a estas dos calles donde las mujeres de vida airada vivían como en los antiguos burdeles medievales; pero esta promiscuidad era ofensiva para su orgullo. ¿Qué más triunfo para la burguesía local y más derrota para su personalidad si se hubiesen contado sus devaneos? No; prefería estar enfermo (OC, II, 536).

Y en Juventud, egolatría, leemos:

La prostitución alta no ofende la vista, no tiene las lacras de la prostitución pobre. El matrimonio es también cómodo para el rico. Para el pobre, la sumisión tiene que ir unida con la vergüenza.

Frecuentar la prostitución baja es codearse, convivir con lo más vil de la sociedad; casarse después sin medios es tener que caer diariamente en el envilecimiento continuo.

Yo, desde la juventud, vi claramente el dilema, y siempre dije: "No; antes la enfermedad, antes la histeria que la sumisión» (OC, V, 170-71).

Tanto los padecimientos de Baroja como los de su personaje, tienen además un origen patológico que el autor ha mencionado frecuentemente en sus obras: Don Pío padecía de una artritis úrica, y a su juicio es esta enfermedad la responsable de su carácter malhumorado y su temperamento pesimista. El artritismo produce una intoxicación que a su vez influye en los nervios, y «Del artritismo a la neurosis y la neurastenia no hay más que un paso» $(O C, \mathrm{~V}, 461)$, explica nuestro autor en La caverna del humorismo (1919) con planteamientos típicamente naturalistas, propios de la época ${ }^{66}$. De esta forma:

66 Baroja es un hombre del siglo XIX y no puede sustraerse a la idea, puesta en boca de Andrés Hurtado, según la cual «el pesimismo y el optimismo son resultados orgánicos como las buenas o malas digestiones» (OC, II, 505). 
El artrítico comienza su vida por la timidez, la melancolía y el dolor de cabeza; sigue luego siendo violento, brutal, de mal humor, hipocondríaco.

También el artritismo podría explicar la ansia neurótica, el anhelo de cambiar de vida, la inquietud. Estas neurosis ansiosas y estas inquietudes, que proceden probablemente de intoxicaciones úricas, toman a veces un aire de misticismo y de sentimiento poético.

En ocasiones, a los cristales de ácido úrico les nacen alas como a los angelitos, aunque generalmente predisponen a la filosofía pesimista y al estado gruñón $(O C, \mathrm{~V}, 462)^{67}$.

\section{Y Andrés Hurtado, durante su estancia en Alcolea:}

Comenzaba a sentir una irritación profunda contra todo.

A los ocho o nueve meses de vivir así, excitado y aplanado al mismo tiempo, empezó a padecer dolores articulares; además, el pelo se le caía abundantemente.

«Es la castidad», dijo.

Era logico; era un neuroartrítico. De chico, su artritismo se había manifestado por jaquecas y por tendencia hipocondríaca. Su estado artrítico se exacerbaba. Se iban acumulando en el organismo las sustancias de desecho, y esto tenía que engendrar productos de oxidación incompleta; el ácido úrico, sobre todo $(O C, \text { II, } 535)^{68}$.

67 En las Memorias, el autor vuelve a insistir: "Con escasos medios, sin protección y sin conocimientos de personas influyentes, he llegado a la vejez y a la vejez de artrítico. Creo que todos los hombres de más de veinte años están ya comenzando a pudrirse. Un artrítico está más podrido aún» (OC, VII, 806); y en La sensualidad pervertida, otro interesante retablo barojiano intensamente autobiografico, el protagonista, Luis Murguía, confiesa: «Cada vez me iba haciendo más solitario, más malhumorado y más distinto de los demás; tenfa un motivo de hipocondría, el artritismo, el dolor frecuente en la cintura y en las articulaciones» (OC, II, 955).

${ }^{68}$ Estas ideas de nuestro autor no son en absoluto originales. En los manuales al uso en la época de Baroja se solía considerar que la irritabilidad de carácter era uno de los resultados normales de la gota y de otras afecciones provocadas por el exceso de ácido úrico: «En fin, estas personas tienen a veces el carácter irritable, inquieto, desigualm, se lee en un libro de texto de la época (LEón MoYnac, Manual de patología y clínica médicas, Madrid, Moya y Plaza Editores, 1878, p. 451); y como remedio terapético se aconseja «un régimen sobrio, más vegetal que animal, absteniéndose de crustáceos, café, licores; el enfermo deberá beber sobre todo agua, y algunos vinos ligeros, y se le aconsejará el ejercicio al aire libre y la hidroterapia» (Ibid., p. 452); exactamente el mismo tratamiento que Hurtado pone en práctica durante su estancia en Alcolea (OC, II, 536), y que en sus aspectos básicos sigue siendo válido hoy en día. Véase también, a propósito de este tema José 
La sexta parte de la obra se inicia con una fecha clave: 1898. En esta época Baroja se halla definitivamente instalado en Madrid, regenta la panadería de doña Juana Nessi, y ha iniciado ya su carrera literaria ${ }^{69}$; Andrés acaba de volver de Alcolea, y sus reflexiones e inquietudes en las semanas anteriores al Desastre, similares a las que experimentó el autor, aparecerán reproducidas años después en las páginas de las Memorias: cierto optimismo inicial, alentado por la euforia general y las bravuconadas de los periódicos; percepción realista del desastre que se avecina, tras una conversación con don Lucas Mallada ${ }^{70}$ - con Iturrioz en la novela-; indignación y asombro tras las derrota (OC, II, 542-43 y VII, 652-54).

Pese a la imposibilidad de hallar nuevas similitudes entre la biografía de Baroja y la trayectoria vital de Andrés Hurtado, la semejanza entre la personalidad y la evolución de ambos sigue siendo evidente en las páginas finales del libro: el autor puede desahogarse a través de ellas, y exponer con toda su crudeza dilemas y problemas íntimos que en sus Memorias y confesiones personales sólo se atreverá a insinuar. Así ocurre con la irritación, el descontento y la sorda agresividad que sentía con frecuencia, y cuyos orígenes deben buscarse en su misantropía, su inadaptación y su pesimismo sin salida ${ }^{71}$ :

Inadaptado al ambiente, he vivido un poco solitario, lo que quizá ha exacerbado mi descontento [explicaba el autor con notable recato en sus Divagaciones apasionadas (1924)]. No es raro, pues, que yo haya hablado mal de todo lo próximo a mí $(O C, \mathrm{~V}, 495)$.

Guimón Ugartechea, «Las ideas médicas de don Pio Baroja», Revista de Occidente, VI, 1968, pp. 225-243; e IGNACio ElizaldE, op. cit., p. 19.

69 Véase, para esta etapa de la biografia barojiana, el apartado correspondiente de las Memorias (OC, VII, 634 y ss.).

70 «Lucas Mallada, el gélogo que, a causa de su pesimismo, era objeto de todas las simpatías de mi tío Pro. Mallada decfa, con frecuencia, que España era un pais ramplón, y mi tío gustó mucho siempre del adjetivo» (Julio CARo BAROJA, op. cit., p. 42). Baroja ha recordado en algún otro pasaje de sus Memorias (OC, VII, 932-33) a este personaje, autor de Los males de la patria (1890), libro situado en la línea del pensamiento regeneracionista, que tanto iba a influir a los autores del 98.

71 «Mi tío no estaba contento con nada: ni la política, ni la literatura, ni el arte, ni las costumbres de la gente que bullfa cuando el era joven le producían agradon (Jullo CARo BAROJA, op. cit., p. 70). Castilla del Pino ha señalado cómo «muchas novelas de Baroja, son la historia de una protesta concluida en fracaso, historia de una impotencia iniciada con la agresión y el iluso intento de vivir la libertad. La conexión impotencia-agresión, que cierra el ćrculo con una desesperanzada conciencia de la impotencia, es un leit-motiv de la obra barojiana” (CARLOS CASTILLA DEL PINO, «Baroja: análisis de una irritación», en JUAN BENET y otros, Barojiana, Madrid, Taurus, 
Mientras que en Juventud, egolatría (1917), además de afirmar que le sugestiona lo que el liberalismo tiene de destructor, pues «todo lo que sea pulverizar la sociedad pasada, me produce una gran alegría» $(O C, \mathrm{~V}, 214-15)$, confesaba, en un tono más airado:

La moral de nuestra sociedad me ha perturbado y desequilibrado.

Por eso la odio cordialmente y le devuelvo, cuanto puedo, todo el veneno de que dispongo. Ahora, que a veces me gusta dar a ese veneno una envoltura artística $(O C, \mathrm{~V}, 171)$.

Al referirse a Andrés Hurtado, en cambio, el autor puede expresar sin velos toda su cólera íntima. Así, ya durante su estancia en Alcolea, el protagonista «comenzaba a sentir una irritación profunda contra todo» $(O C, \mathrm{II}, 535) ; \mathrm{y}$ aunque prefiere encerrarse en su habitación y leer:

Andrés no era de estos hombres que consideraban el leer como un sucedáneo de vivir; él leía porque no podía vivir. Para alternar con esta gente del casino, estúpida y malintencionada, prefería pasar el tiempo en su cuarto, en aquel mausoleo blanqueado y silencioso.

Pero ¡con qué gusto hubiera cerrado los libros si hubiera habido algo importante que hacer; algo como pegarle fuego al pueblo o reconstruirlo! (OC, II, 534-35).

Más tarde, cuando el personaje ejerce como médico de higiene, «La irritación le hacía ser en sus palabras violento y brutal» $(O C, \mathrm{II}, 551)$; y tras la derota española en Cuba y Filipinas:

La cólera y la irritación se habían hecho crónicas en Andrés; el calor, el andar al sol, le producían una sed constante, que le obligaba a beber cerveza y cosas frías que le estragaban el estómago.

Ideas absurdas de destrucción le pasaban por la cabeza. Los domingos, sobre todo, cuando cruzaba entre la gente a la vuelta de los

1972, p. 51). Isabel Criado ha esbozado, por su parte, una explicación psicoanalística de la agresividad barojiana. De acuerdo con ella: «La misma falsa aceptación del autoritarismo paterno va sedimentándose en un fondo de hostilidad contra toda norma, toda estructura, toda situación; y en ese fondo arraiga una actitud de desafí, dirigida a la vida en general, una actitud de agresividad social» (IsABEL CRIADo Miguel, op. cit., p. 65). 
toros, pensaba en el placer que sería para él poner en cada bocacalle una media docena de ametralladoras y no dejar uno de los que volvían de la estúpida y sangrienta fiesta $(O C, 11,556)^{72}$.

En cuanto al trabajo de Hurtado como médico de higiene, aunque no sea reflejo de una experiencia personal directa, sirve para introducir en la novela el problema de la prostitución, terrible lacra frecuentemente denunciada en las páginas juveniles del autor ${ }^{73}$; o para dejar constancia de acontecimientos vividos recientemente, como ocurre con la escena en que Andrés recuerda el velatorio de un autor bohemio, Rafael Villasús, en el que se ha visto una contrafigura de Alejandro Sawa, escritor contemporáneo muerto en penosas circunstancias en 1909, y precedente literario del protagonista de Luces de bohemia, Max Estrella ${ }^{74}$.

Es en estas páginas finales del libro cuando el alejamiento de la enfermedad y la miseria, la tranquilidad que le proporcionan el matrimonio y el trabajo metódico, la vida ordenada y la posibilidad de actuar dentro de un círculo limitado, tal como le había propuesto Iturrioz (OC, II, 493), preparan a Andrés para conocer ese estado de serenidad - la ataraxia ${ }^{75}$ - que ya había intentado alcanzar en Alcolea, aunque en vano. Entonces, durante su época de médico rural:

...la comida escasa y sólo vegetal, el baño, el ejercicio al aire libre, le iban haciendo un hombre sin nervios. Ahora se sentía como divinizado por su ascetismo, libre; comenzaba a vislumbrar ese estado de «ataraxia», cantado por los epicúreos y los pirronianos (OC, II, 536).

72 Recuérdese la actitud similar de Fernando Ossorio durante su estancia en Yécora: «Él hubiese querido tener en su mano la máquina infernal, el producto terrible engendrador de la muerte, para arrojarlo sobre el pueblo y aniquilarlo y reducirlo a cenizas y terminar para siempre con su vida miserable y raquitica» $(O C, \mathrm{VI}, 105)$.

73 Además de la trilogía de La lucha por la vida, véase el cuento titulado «La sombra», incluido en Vidas sombrías, (OC, VI, 999); y «Cabriola. Dulce hipocresía», publicado en El Pais, 21 de septiembre de 1900, y reproducido en Escritos de juventud, edic. cit., pp. 118-120.

74 Para la relación entre las dos versiones de la muerte de Sawa, y la posible influencia de $E l$ árbol en la génesis de Luces, véase ILdEFonso MANUEl GIL, «De Baroja a Valle-Inclán», en ValleInclán, Azorín y Baroja, Madrid, Seminarios y Ediciones, 1975, pp. 9-46. Baroja también ha recordado a este personaje en el volumen de las Memorias titulado Finales del siglo XIX y principios del $X X(O C, \mathrm{~V}, 735-38)$.

75 Aunque referido a obras posteriores a El árbol, véase a propósito de este tema el trabajo de Donald L. Shaw, «The concept of "ataraxia" in the Later Novels of Baroja», Bulletin of Hispanic Studies, XXXIV, 1957, pp. 29-35; y CARMEN Iglesias, op. cit., pp. 38-40. 
Ahora, junto a Lulú, ese estado de bienestar vislumbrado en las largas siestas de Alcolea está a punto de ser una realidad:

Andrés estaba desconocido. El método de vida, el no tener que sufrir el sol ni subir escaleras ni ver miserias, le daba una impresión to tranquilidad, de paz.

Explicándose como un filosofo, hubiera dicho que la sensación ae conjunto de su cuerpo, la cenesthesia, era en aquel momento pasiva, tranquila, dulce; su bienestar físico le preparaba para ese estado de perfección y de equilibrio intelectual, que los epicúreos y los estoicos griegos llamaron ataraxia, el paraíso del que no cree $(O C$, II, 565).

Y es en esa búsqueda de la serenidad donde encontramos sin duda al Baroja más auténtico, el mismo que en 1918, muy pocos años después de publicarse El árbol de la ciencia, exclama:

¡Ataraxia ¡Ataraxia! ¿Serás también tú un mito? ¡Serenidad! ¡Serenidad! Si existes, ¿por qué te olvidas así de mí? (Las horas solitarias, $O C, \mathrm{~V}, 366$ ).

Y sin embargo, aunque viva feliz en medio del oasis, el pesimismo le hace a Andrés sospechar «que la calma no iba a ser duradera», que muy pronto algo vendría «a descomponer este bello equilibrio» (OC, II, 564), que la puerta estaba a punto de abrirse para dar otra vez paso al desorden y el dolor. Y, en efecto, el embarazo de Lulú hace que Andrés viva de nuevo «en una angustia continua» (OC, II, 567), mientras que poco a poco se hacen realidad los temores del tío de Andrés:

...yo no creo, como Calderón, que el delito mayor del hombre sea el haber nacido. Esto me parece una tontería poética. El delito mayor del hombre es hacer nacer $(O C, \mathrm{II}, 561)$.

Había advertido Iturrioz a su sobrino; y también:

... sólo el peligro, sólo la posibilidad de engendrar una prole enfermiza, debía bastar al hombre para no tenerla. El perpetuar el dolor en el mundo me parece un crimen.

No, no debe ser lícito engendrar seres que vivan en el dolor (OC, II, 561-62). 
Y en estas reflexiones nos parece sentir una vez más la voz del propio autor, temeroso ante las consecuencias imprevisibles que para el hombre enfermo y desequilibrado pueden tener el matrimonio y la paternidad ${ }^{76}$.

De otro lado, mientras ejerce como médico de higiene, sin hallar «en su vida nada sonriente, nada amable», Andrés se siente «como un hombre desnudo que tuviera que andar atravesando zarzas» $(O C$, II, 551). Más tarde, tras el matrimonio:

Muchas veces se le figuraba que en su vida había una ventana abierta a un abismo. Asomándose a ella, el vértigo y el horror se apoderaban de su alma (OC, II, 564).

Y cuando tiene la certeza de que va a ser padre:

Ya Andrés vivía en una angustia continua. La ventana, que en su vida se abría a aquel abismo que le producía vértigo, estaba de nuevo de par en par ( $O C$, II, 567).

Todas estas afirmaciones son sin duda hiperb6licas, una concesión a la retórica y a la necesaria búsqueda de la expresividad incisiva, y, sin embargo, en las páginas de Juventud, egolatría es el autor quien nos recuerda hasta qué punto son sinceras sus palabras, y en qué medida su criatura, pese al ropaje literario que la envuelve, no es más que un doble, apenas disfrazado, del propio creador:

Cuando hojeo los libros míos, ya viejos, me da la impresión de que muchas veces, como un sonámbulo en completa inconsciencia, he andado por la cornisa de un tejado a riesgo de caerme, $y$ otras me he metido por caminos llenos de zarzas, en donde me he arañado la piel $(O C, \mathrm{v}, 164)$.

El desenlace de la novela y la trayectoria posterior de su creador difieren por completo, qué duda cabe, aunque don Pío ha confesado que durante su estancia en Valencia, hacia 1892, sentía con frecuencia «un pesimismo agudo», que le empujaba a hacer estas reflexiones:

76 Véase IsABEl CRIADO Miguel, op. cit., pp. 237 y ss. 
Me parecía que todo me iba a salir mal en la vida, y quizá lo mejor era acabar lo antes posible (OC, VII, 602).

Sin embargo, Baroja está lejos de aplicarse a sí mismo el drástico remedio terapéutico por el que opta Andrés Hurtado, porque ha encontrado en la literatura una vía adecuada para purgar las dolencias de su espíritu, de manera que:

En lugar de resolver su propio problema con esa muerte farmacéutica, Baroja ha escrito veintiséis o veintiocho volúmenes, que se abren como otros tantos bostezos de aburrimiento trascendental ante un mundo donde todo es insuficiente ${ }^{77}$.

77 José Ortega y Gasset, «Ideas sobre Pío Baroja», en Pio Baroja, edic. de Javier Martínez Palacio, p. 68. 